\title{
Ischaemic heart disease in the elderly
}

\author{
R. D. KENNEDY, G. R. ANDREWS, AND F. I. CAIRD \\ From the University Department of Geriatric Medicine, University of Glasgow
}

Studies were made for evidence of heart disease on 501 people aged 65 and more living at home; 22.4 per cent had clinical and/or electrocardiographic evidence of ischaemic heart disease. The prevalence of ischaemic heart disease increased with age, and was slightly greater in men than women.

The frequency of ischaemic heart disease increased with increasing current cigarette consumption and with total cigarette consumption. There was no increase in relation to any of the following possible risk factors: systolic and diastolic blood pressure, blood glucose, serum cholesterol, skinfold thickness, percentage of ideal body weight.

The survival over a 5-year period of all subjects with ischaemic heart disease did not differ significantly from that of all subjects together, but the mortality of subjects with ischaemic heart disease and an abnormal electrocardiogram was 1.5 to 2 times that of subjects in whom ischaemic heart disease was diagnosed on the basis of angina pectoris or past cardiac infarction, the electrocardiogram being normal.

The majority of studies of ischaemic heart disease in old age have been concerned with the modes of presentation of acute cardiac infarction (Rodstein, 1956; Pathy, 1967), and the detailed and extensive reports on the 'risk factors' for the disease (see Kannel and Dawber, 1974; Joint Working Party, 1976; Reid et al., 1976) barely consider these in relation to the elderly, even though ischaemic heart disease is the commonest single cause of death in old age (Caird and Kennedy, 1976). Of the many 'risk factors' identified with varying degrees of certainty, none, except possibly high blood pressure (Kannel, 1976), has been shown to carry with it an excess risk of ischaemic heart disease in old age (Elmfeldt et al., 1976). Apart from studies of the survival of elderly patients admitted to hospital with acute cardiac infarction (Biörck et al., 1958; Librach et al., 1976), and of the excess mortality associated with a variety of electrocardiographic abnormalities (Caird et al., 1974), there is little information on the natural history and prognosis of ischaemic heart disease manifest late in life.

The present study was undertaken to establish the prevalence of ischaemic heart disease in a random sample of the elderly population, to identify factors related to this prevalence, and to investigate the survival of old people with respect to the presence or absence of clinically diagnosable ischaemic heart disease. The study is part of a detailed clinical, laboratory, and nutritional survey of old people living at home.

Received for publication 10 February 1977

\section{Methods}

Two stratified random samples, totalling 501 subjects, were drawn from people aged 65 and over living at home, the first from the whole elderly population of the town of Kilsyth (Andrews et al., 1971), the second from six general practices in north Glasgow, as described by McLennan et al. (1973). The findings in the two samples were virtually identical, and they have, therefore, been combined for the purposes of the present investigation.

A full medical history, supplemented where appropriate by reference to general practitioner and hospital records, and including details of current drug therapy, was taken from each participant. It also included standard questionnaires on angina pectoris (Rose and Blackburn, 1968) and smoking habits (Medical Research Council, 1966). Total cigarette consumption was estimated by multiplying the number of cigarettes smoked by the number of years for which each subject admitted to smoking cigarettes. Subjects who smoked both pipe and cigarette tobacco were included in respect of their cigarette consumption.

A clinical examination was carried out, and in all except 14 subjects ( $3 \%$ ) a standard 13-lead electrocardiogram was recorded, the tracings being classified by two observers according to the Minnesota code (Rose and Blackburn, 1968; Kennedy and Caird, 1972). In all subjects except those whose condition necessitated examination at home rather than at a clinic a standard six-foot posteroanterior 
chest radiograph was taken, and height and weight recorded.

The percentage of the subject's ideal weight was calculated from the nomogram of Anderson (1948). The thickness of skinfolds over the right subscapular region and right triceps were recorded using Harpenden calipers, and the arithmetic sum in $\mathrm{mm}$ of the two measurements taken as 'skinfold thickness'. Blood was taken by venepuncture between $11.00 \mathrm{a} . \mathrm{m}$. and $2.00 \mathrm{p} . \mathrm{m}$. for measurement of glucose by Autoanalyser as 'true glucose' and cholesterol by the method of Annan and Isherwood (1969). Risk factors with continuous frequency distributions (i.e. systolic and diastolic blood pressure, blood glucose, serum cholesterol, skinfold thickness, and percentage of ideal weight) were analysed by dividing the subjects into tertiles of the frequency distributions, after exclusions as detailed in Table 1. Table 2 gives the inclusive ranges of the middle tertiles of these continuous distributions.

Subjects in the first (Kilsyth) sample were followed up for 5 years, and those in the second (Glasgow) sample for 3 years after their initial examination, and their survival status, and if dead their date of death, determined. Survival curves were constructed by life table methods (Merrell and Shulman, 1955).

\section{Diagnostic criteria}

Ischaemic heart disease was diagnosed on the basis of positive answers to the questions on angina pectoris (in the absence of evidence of significant aortic valve disease), and/or a documented history of cardiac infarction, and/or an electrocardiogram showing codable $\mathrm{Q} / \mathrm{QS}$ items according to the Minnesota code. Table 3 shows the diagnostic cri- teria in the 112 subjects in whom ischaemic heart disease was diagnosed.

Hypertensive heart disease was diagnosed in the presence of an electrocardiogram showing 'probable left ventricular hypertrophy' (i.e. both voltage and ST-T changes; Kannel et al., 1970; Kennedy and Caird, 1972; Campbell et al., 1974) and either an arterial blood pressure of $180 / 110 \mathrm{mmHg}$ or

Table 1 Subjects excluded from individual analyses

\begin{tabular}{llc}
\hline & Reason for exclusion & Number \\
\hline Smoking & Not recorded & 4 \\
Blood pressure & Antihypertensive therapy & 58 \\
Blood glucose & Not recorded & 27 \\
& Known diabetes & 11 \\
Serum cholesterol & Thiazides & 44 \\
Skinfold thickness & Total & 82 \\
Per cent of ideal weight & Not recorded & 51 \\
& Not recorded & 102 \\
& & 54 \\
\hline
\end{tabular}

Table 2 Range of middle tertile of continuous variables

\begin{tabular}{|c|c|c|c|c|}
\hline $\begin{array}{l}\text { Sex } \\
\text { Age (y) }\end{array}$ & $\begin{array}{l}M \\
65-74\end{array}$ & $75+$ & $\begin{array}{l}F \\
65-74\end{array}$ & $75+$ \\
\hline $\begin{array}{l}\text { Systolic blood pressure } \\
(\mathrm{mmHg})\end{array}$ & $155-170$ & $155-180$ & $160-185$ & $165-195$ \\
\hline $\begin{array}{l}\text { Diastolic blood pressure } \\
\text { (mmHg) }\end{array}$ & $85-100$ & $85-100$ & $89-105$ & $95-105$ \\
\hline $\begin{array}{l}\text { Blood glucose }(\mathrm{mmol} / \mathrm{l})^{\star} \\
\text { Serum cholesterol }(\mathrm{mmol} / \mathrm{l})^{\star} \\
\text { Skinfold thickness }(\mathrm{mm}) \\
\text { Per cent of ideal weight }\end{array}$ & $\begin{array}{l}4 \cdot 9-6 \cdot 1 \\
5 \cdot 9-6 \cdot 9 \\
17-27 \\
97-115\end{array}$ & $\begin{array}{l}5 \cdot 3-6 \cdot 1 \\
5 \cdot 6-6 \cdot 6 \\
17-22 \\
94-104\end{array}$ & $\begin{array}{c}4 \cdot 9-6 \cdot 1 \\
6 \cdot 9-8 \cdot 2 \\
23-33 \\
101-119\end{array}$ & $\begin{array}{c}5 \cdot 4-6 \cdot 3 \\
6 \cdot 5-7 \cdot 9 \\
17-29 \\
101-118\end{array}$ \\
\hline
\end{tabular}

*For conversion from $S I$ units to traditional units: glucose: $1 \mathrm{mmol} / 1$ $\simeq 18 \mathrm{mg} / 100 \mathrm{ml}$; cholesterol: $1 \mathrm{mmol} / 1 \simeq 38.6 \mathrm{mg} / 100 \mathrm{ml}$.

Table 3 Diagnostic criteria for ischaemic heart disease

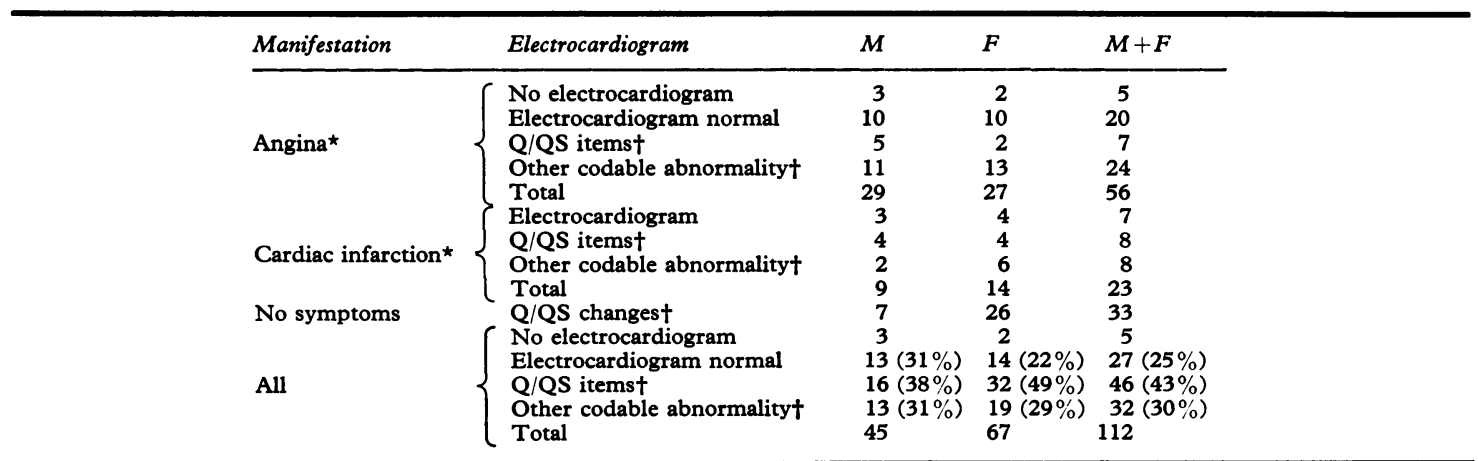

^From questionnaire.

tSee text for definition. 
more, or a lower blood pressure when antihypertensive drugs were being taken. Conventional criteria were used for the diagnosis of valvular heart disease (Bedford and Caird, 1960); pulmonary heart disease was diagnosed when the electrocardiogram showed right ventricular hypertrophy (Goodwin and Abdin, 1959) and there were symptoms and signs of severe chronic respiratory disease. 'Mixed' heart disease was considered present when criteria for more than one form of definite heart disease were met in an individual subject. 'Definite unclassifiable' heart disease was diagnosed when there was no doubt of cardiac abnormality (e.g. left bundle-branch block or atrial fibrillation) but the available evidence did not allow a convincing diagnostic classification. Heart disease was described as 'doubtful' when evidence of cardiac abnormality was not beyond doubt (e.g. $T$ wave flattening, or a minor increase in cardiothoracic ratio on the chest radiograph).

\section{Results}

\section{PREVALENCE OF HEART DISEASE}

The prevalence of the various forms of heart disease diagnosed in the 501 subjects is shown in Table 4: 112 subjects $(22.4 \%)$ had ischaemic heart disease, 11 of whom also fulfilled the criteria for hypertensive heart disease. Four men and 24 women had only hypertensive heart disease as defined. Three men and 19 women had valve disease; of these, 5 had mitral regurgitation of uncertain origin, 5 rheumatic mitral stenosis and regurgitation, 11 aortic stenosis with or without regurgitation, and 1 'isolated aortic regurgitation' (Bedford and Caird, 1960). Three men had pulmonary heart disease. Fifty-three subjects $(11 \%)$ had 'definite unclassifiable' heart disease as defined, and $28(6 \%)$ had 'doubtful' heart disease. In all, 43 per cent had definite heart disease, the proportion being slightly greater in men than in women, and increasing with age. Of those with definite heart disease as defined, 51 per cent had ischaemic heart disease.

Table 5 shows the prevalence of ischaemic heart disease by age and sex in greater detail. It was present more often in men $(25 \%)$ than in women $(21 \%)$, the male/female prevalence ratio being $1 \cdot 1$ between the ages of 65 and 74, and 1.2 over the age of 75 . Ischaemic heart disease increased in frequency with age in both sexes.

\section{RISK FACTORS FOR ISCHAEMIC HEART DISEASE}

Of subjects who had never smoked, 17 per cent had ischaemic heart disease, as compared with 29 per cent of current cigarette smokers, 26 per cent of ex-cigarette smokers, and 23 per cent of current smokers of pipes or cigars (Table 6). The difference between current smokers and those who have never smoked is significant at the 2.5 per cent level. There is also a statistically significant trend in the prevalence of ischaemic heart disease in relation to total cigarette consumption (Table 7).

Fig. 1 to 3 show the prevalence of ischaemic heart

Table 4 Prevalence of heart disease

\begin{tabular}{|c|c|c|c|c|c|}
\hline $\begin{array}{l}\text { Age (y) } \\
\text { Sex }\end{array}$ & $\begin{array}{l}65-74 \\
M\end{array}$ & $F$ & $\begin{array}{l}75+ \\
M\end{array}$ & $F$ & Total \\
\hline No. of subjects & 102 & 167 & 79 & 153 & 501 \\
\hline Iscinaemic & 21 & 29 & 20 & 31 & $101(20 \%)$ \\
\hline Hypertensive & 1 & 9 & 3 & 15 & $28(6 \%)$ \\
\hline Valvular & 0 & 8 & 3 & 11 & $22(4 \%)$ \\
\hline Pulmonary & 2 & $\mathbf{0}$ & 1 & 0 & $3(0.6 \%)$ \\
\hline Mixed ischaemic and hypertensive & 1 & 3 & 3 & 4 & $11(2 \%) \mu$ \\
\hline Unclassifiable & 14 & 8 & 14 & 17 & $53(11 \%)$ \\
\hline Total definite heart disease & $39(38 \%)$ & $57(34 \%)$ & $44(56 \%)$ & $78(51 \%)$ & $218(43 \%)$ \\
\hline Doubtful heart disease & 10 & 4 & 1 & 13 & $28(6 \%)$ \\
\hline No heart disease & $53(52 \%)$ & $106(64 \%)$ & $34(43 \%)$ & $62(61 \%)$ & $255(51 \%)$ \\
\hline
\end{tabular}

Table 5 Prevalence of ischaemic heart disease by age and sex

\begin{tabular}{|c|c|c|c|c|c|c|c|c|c|c|c|}
\hline $\begin{array}{l}\text { Age (y) } \\
\text { Sex }\end{array}$ & $\begin{array}{l}65-69 \\
M\end{array}$ & $\boldsymbol{F}$ & $\begin{array}{l}70-47 \\
M\end{array}$ & $F$ & $\begin{array}{l}75-79 \\
M\end{array}$ & $F$ & $\begin{array}{l}80-84 \\
M\end{array}$ & $F$ & $\begin{array}{l}85+ \\
M\end{array}$ & $F$ & $\begin{array}{l}\text { All subjects } \\
M+F\end{array}$ \\
\hline $\begin{array}{l}\text { No. of subjects } \\
\text { No. with ischaemic heart disease } \\
\% \text { with ischaemic heart disease }\end{array}$ & $\begin{array}{l}58 \\
12 \\
21\end{array}$ & $\begin{array}{l}85(1) \\
20(1) \\
24\end{array}$ & $\begin{array}{l}44(1) \\
10 \\
23\end{array}$ & $\begin{array}{l}82(4) \\
12(1) \\
15\end{array}$ & $\begin{array}{l}47(4) \\
14(3) \\
30\end{array}$ & $\begin{array}{l}80(1) \\
19 \\
24\end{array}$ & $\begin{array}{r}21(1) \\
6 \\
28\end{array}$ & $\begin{array}{l}46(2) \\
8 \\
17\end{array}$ & $\begin{array}{r}11 \\
3 \\
27\end{array}$ & $\begin{array}{r}27 \\
8 \\
30\end{array}$ & $\begin{array}{l}501(14) \\
112(5) \\
22\end{array}$ \\
\hline
\end{tabular}

Numbers in brackets are subjects without an electrocardiogram. 
Table 6 Frequency of ischaemic heart disease and current smoking habits

\begin{tabular}{|c|c|c|c|c|c|c|}
\hline Sex & $\begin{array}{l}M \\
\text { No. }\end{array}$ & $\%$ & $\begin{array}{l}F \\
\text { No. }\end{array}$ & $\%$ & $\begin{array}{l}M+F \\
\text { No. }\end{array}$ & $\%$ \\
\hline $\begin{array}{l}\text { Never smoked } \\
\text { Current smokers: }\end{array}$ & $2 / 16$ & 13 & $44 / 249$ & 18 & $46 / 265$ & 17 \\
\hline 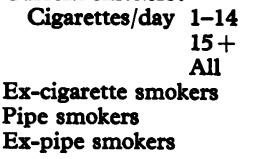 & $\begin{array}{l}10 / 46 \\
9 / 31 \\
19 / 77 \\
9 / 39 \\
9 / 39 \\
1 / 5\end{array}$ & $\begin{array}{l}22 \\
29 \\
25 \\
23 \\
23\end{array}$ & $\begin{array}{l}12 / 24 \\
4 / 20 \\
16 / 44 \\
6 / 19 \\
=\end{array}$ & $\begin{array}{l}50 \\
20 \\
36 \\
32 \\
-\end{array}$ & $\begin{array}{l}22 / 70 \\
13 / 51 \\
35 / 121 \\
15 / 58 \\
9 / 39 \\
1 / 5\end{array}$ & $\begin{array}{l}31 \\
26 \\
29 \star \\
26 \\
23\end{array}$ \\
\hline
\end{tabular}

*Significantly different from subjects who never smoked: $\chi^{2}=6 \cdot 12$, d.f. $=1, P<0.025$.

Table 7 Frequency of ischaemic heart disease and total cigarette consumption

\begin{tabular}{llllllll}
\hline Sex & $M$ & & $F$ & & $M+F$ \\
& No. & $\%$ & No. & $\%$ & No. & $\%$ \\
\hline $\begin{array}{l}\text { Non-smokers } \\
\text { Total cigarette }\end{array}$ & $<200000$ & $2 / 16$ & 13 & $44 / 249$ & 18 & $46 / 265$ & $17^{\star}$ \\
consumption & $>200000$ & $26 / 91$ & 29 & $8 / 27$ & 30 & $34 / 118$ & $29^{\star}$ \\
& & & & & & &
\end{tabular}

*Trend significant: $\chi^{2}=7.80$, d.f. $2, P<0.025$.

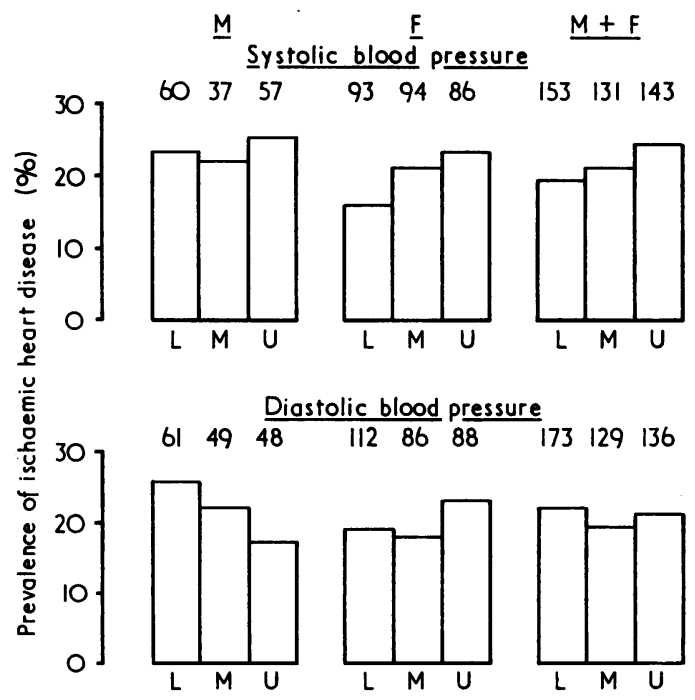

Fig. 1 Prevalence of ischaemic heart disease by tertiles of the frequency distributions of systolic and diastolic blood pressure in men, in women, and in both sexes together. There are no significant gradients of prevalence. $L, M, U$ : lower, middle, and upper tertiles. Number of subjects in each group is shown above.

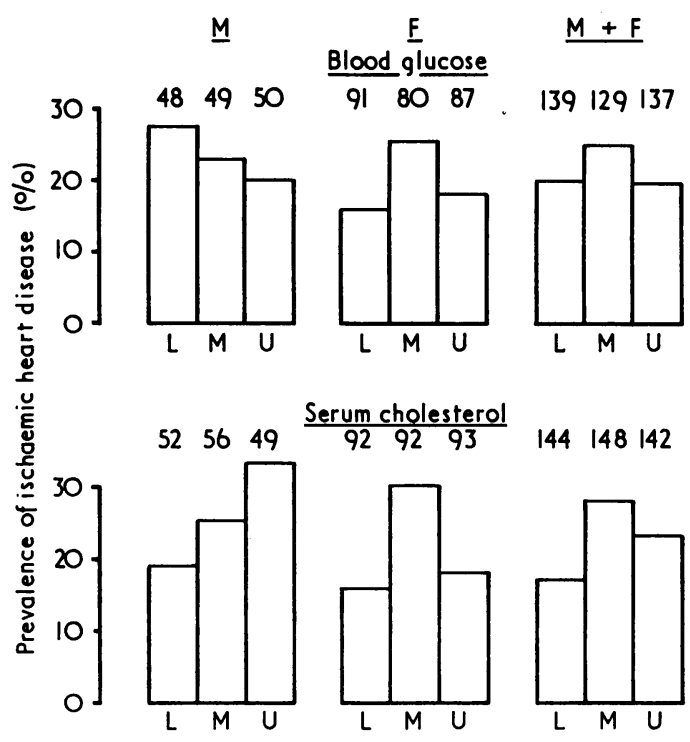

Fig. 2 Prevalence of ischaemic heart disease by tertiles of the frequency distributions of blood glucose and serum cholesterol, in men, in women, and in both sexes together. There are no significant gradients of prevalence. $L, M, U$ : lower, middle, and upper tertiles. Number of subjects in each group is shown above.

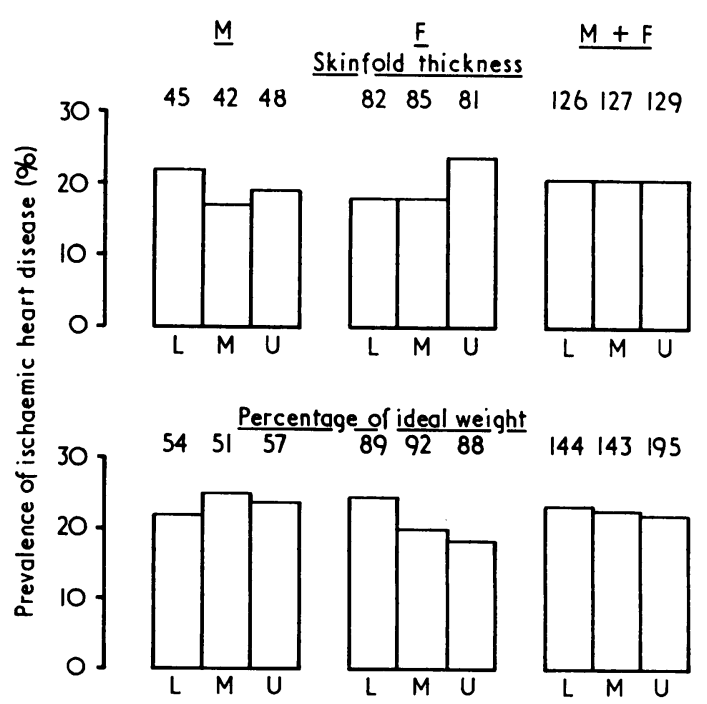

Fig. 3 Prevalence of ischaemic heart disease by tertiles of the frequency distributions of skinfold thickness and percentage of ideal weight, in men, in women, and in both sexes together. There are no significant gradients of prevalence. $L, M, U$ : lower, middle, and upper tertiles. Number of subjects in each group is shown above. 
disease by tertiles of the frequency distributions of systolic and diastolic blood pressure, blood glucose, serum cholesterol, skinfold thickness, and percentage of ideal weight. In none is there any significant gradient of prevalence. In the case of serum cholesterol, prevalence in women is highest in the middle tertile.

\section{SURVIVAL IN ISCHAEMIC HEART DISEASE}

The survival of the whole group of subjects with ischaemic heart disease does not differ significantly from that of an age- and sex-matched sample of the whole group of subjects (Table 8), but the survival of subjects whose electrocardiograms were abnormal (i.e. showed either Q/QS or other items) was significantly less than that of subjects with normal electrocardiograms in whom ischaemic heart disease was diagnosed solely on the basis of a history of angina or a past cardiac infarct.

\section{Discussion}

The reasons for regarding the population studied as representative at least of the elderly in urban Scotland, and probably more widely, are discussed by McLennan et al. (1973).

The diagnostic criteria for ischaemic heart disease used in the present study are probably as realistic as can be achieved in elderly people. It is known that questions relating to the presence of angina may be answered in the affirmative at one examination and in the negative at a second examination (Rose, 1968); the true prevalence of angina in any group is therefore likely to be underestimated in a single cross-sectional study. It will be seen from Table 3 that the electrocardiogram showed no codable abnormality in 40 per cent of the subjects who gave a history of angina. It is of course possible that the exertional chest pain recorded as angina by the answers to the questionnaire was not in fact of cardiac origin in some cases. But the electrocardiogram was normal in 7 of the $23(30 \%)$ in

Table 8 Survival of subjects with ischaemic heart disease

\begin{tabular}{lcccccc}
\hline & \multicolumn{5}{c}{ Survivors $\%( \pm S E)$ at years } \\
& No. & 1 & 2 & 3 & 4 & 5 \\
\hline All cases & 112 & $92 \pm 3$ & $88 \pm 3$ & $74 \pm 4$ & $65 \pm 5$ & $56 \pm 5$ \\
Expected & & 93 & 86 & 78 & 71 & 65 \\
Electrocardiogram & & & & & \\
$\quad$ normal & 32 & 100 & 100 & $91 \pm 5$ & $79 \pm 8$ & $79 \pm 8$ \\
Q/QS items & 46 & $89 \pm 5$ & $87 \pm 5$ & $67 \pm 7$ & $67 \pm 7$ & $50 \pm 10$ \\
Other abnormality & 29 & $86 \pm 6$ & $72 \pm 8$ & $61 \pm 9$ & $48 \pm 10$ & $37 \pm 10$ \\
\hline
\end{tabular}

«Expected mortality of all subjects, adjusted for age and sex. whom the criterion for the diagnosis of ischaemic heart disease was a documented cardiac infarct. The findings of Kitchin et al. (1973) in the elderly are very similar. Of the 107 subjects in the present study in whom ischaemic heart disease was diagnosed and an electrocardiogram recorded, 43 per cent had Q/QS abnormalities, 30 per cent had other codable abnormalities, and 25 per cent had a normal electrocardiogram.

It is possible that some instances of 'definite unclassifiable' heart disease were of ischaemic origin and should, therefore, be so classified, but it would be unwarranted and unrealistic to consider them all to be so. Certainly many cases both of bundlebranch block and of atrial fibrillation in old age are unrelated to coronary artery disease (Davies, 1976; Pomerance, 1976). The frequency of hypertensive heart disease depends largely on the definition of hypertension employed. The prevalences recorded in the present study for valvular and pulmonary heart disease are in line with previous estimates (Beford and Caird, 1960; Pomerance, 1976; Campbell et al., 1974).

Male sex is a most important risk factor for ischaemic heart disease in the young and middle aged (Joint Working Party, 1976), but, as Table 5 shows, this is not so in the elderly, in whom the prevalence rate in men exceeds that in women by only 10 to 20 per cent (Kitchin et al., 1973).

Analysis of other risk factors shows a significant association between ischaemic heart disease and cigarette smoking, which is demonstrable in both sexes and whether current or total cigarette consumption is considered (Tables 6 and 7). Kitchin et al. (1973), whose study of old people at home closely resembles the present investigation, failed to find such an association, but prospective data from the Framingham survey, reported by Kannel (1976), suggests that cigarette smoking retains its place as a risk factor for ischaemic heart disease in old age. Kannel also stresses the importance of high blood pressure as a risk factor for ischaemic heart disease in old age, but this is not confirmed either by Kitchin et al. (1973) or by the present study; both of these include many subjects over the age of 75 years. Neither blood glucose nor serum cholesterol level are associated with the presence of ischaemic heart disease (Fig. 2) as Kannel (1976) has also shown. In the case of serum cholesterol level, prevalence of ischaemic heart disease is highest in women in the middle tertile of the range, and it is of interest that Carlson and Böttiger (1972) in a prospective study found the highest incidence of episodes of ischaemic heart disease in elderly men whose serum cholesterol was in the middle of the frequency distribution. 
Obesity is not of great importance as a risk factor for ischaemic heart disease in middle age (Epstein, 1973; Joint Working Party, 1976), and it is thus not surprising to find no association between either measure of obesity and ischaemic heart disease in old people (Fig. 3); indeed the gradient of prevalence is negative (i.e. ischaemic heart disease is commoner among the thinner subjects).

It seems clear, therefore, that cigarette smoking is the only one of the commonly demonstrable risk factors for ischaemic heart disease which can be positively identified in the elderly. Two possible explanations for the discrepancy between the findings in the middle-aged and in the elderly suggest themselves. It may be that those most exposed to risk factors in early and middle life do not survive into old age, or that all the risk factors continue to operate in old age, but each individually to a less than significant intensity, so that it is the duration of exposure to all factors together that comes to predominate. If this were so, it might well be that in old age no single risk factor could be shown to be significantly associated with the presence of ischaemic heart disease.

It is somewhat surprising that no excess mortality can be shown in old age for ischaemic heart disease when all subjects are taken together (Table 8). However, abnormality of the electrocardiogram, rather than the symptom of angina with a normal electrocardiogram, is shown to carry an excess mortality, as has been previously shown (Caird et $a l ., 1974)$. The difference in mortality between those with an abnormal electrocardiogram and that expected for the whole group of subjects is of the same order ( 1.5 to 2 fold) as was found by Biörck et al. (1958) and Librach et al. (1976) for elderly people discharged from hospital after a myocardial infarct, and is much less than for young or middle-aged patients with ischaemic heart disease.

This study shows clearly a substantial number of differences between ischaemic heart disease in middle and in later life. In old age the male predominance is very much smaller, the risk factors except cigarette smoking much less obvious, and the outlook for survival relative to other people of the same age much less unfavourable.

It is a pleasure to thank the general practitioners in Kilsyth and Glasgow for permission to study patients under their care; our colleagues in the survey, Drs. A. J. Akhtar, A. J. J. Gilmore, and W. J. McLennan, Miss A. Crombie, S.R.N., and Miss J. MacDougall, S.R.N., for their assistance; Dr. Gilmore and Dr. S. Acland for the follow-up data; and the subjects for their co-operation.

\section{References}

Anderson, A. B. (1948). Nomogram. Cited in The Practice of Endocrinology, p. 319. By R. Greene. Eyre and Spottiswoode, London. 1948.

Andrews, G. R., Cowan, N. R., and Anderson, W. F. (1971). The practice of geriatric medicine in the community. In Problems and Progress in Medical Care: Essays on Current Research, 5th Series, p. 58. Ed. by G. McLachlan. Oxford University Press, London.

Annan, W., and Isherwood, D. M. (1969). An automated method for the direct determination of total serum cholesterol. Fournal of Medical Laboratory Technology, 26, 202211.

Bedford, P. D., and Caird, F. I. (1960). Valvular Disease of the Heart in Old Age. Churchill, London.

Biörck, G., Sievers, J., and Blomqvist, G. (1958). Studies on myocardial infarction in Malmö, 1935-1954. Acta Medica Scandinavica, 162, 81-97.

Caird, F. I., Campbell, A., and Jackson, T. F. M. (1974). Significance of abnormalities of electrocardiogram in old people. British Heart Fournal, 36, 1012-1018.

Caird, F. I., and Kennedy, R. D. (1976). Epidemiology of heart disease in old age. In Cardiology in Old Age, p. 1. Ed. by F. I. Caird, J. L. C. Dall, and R. D. Kennedy. Plenum Press, New York and London.

Campbell, A., Caird, F. I., and Jackson, T. F. M. (1974). Prevalence of abnormalities of electrocardiogram in old people. British Heart fournal, 36, 1005-1011.

Carlson, L. A., and Böttiger, L. E. (1972). Ischaemic heart disease in relation to fasting values of plasma triglycerides and cholesterol. Lancet, 1, 865-868.

Davies, M. J. (1976). Pathology of the conduction system. In Cardiology in Old Age, p. 57. Ed. by F. I. Caird, J. L. C. Dall, and R. D. Kennedy. Plenum Press, New York and London.

Elmfeldt, D., Wilhelmsson, C., Vedin, A., Tibblin, G., and Wilhelmsen, L. (1976). Characteristics of representative male survivors of myocardial infarction compared with representative population samples. Acta Medica Scandinavica, 199, 387-398.

Epstein, F. H. (1973). Coronary heart disease epidemiology revisited. Circulation, 48, 185-194.

Goodwin, J. F., and Abdin, Z. H. (1959). The cardiogram of congenital and acquired right ventricular hypertrophy. British Heart fournal, 21, 523-544.

Joint Working Party (1976). Prevention of coronary heart disease. Fournal of the Royal College of Physicians of London, 10, 213-275.

Kannel, W. B. (1976). Blood pressure and the development of cardiovascular disease in the aged. In Cardiology in Old Age, p. 143. Ed. by F. I. Caird, J. L. C. Dall, and R. D. Kennedy. Plenum Press, New York and London.

Kannel, W. B., and Dawber, T. R. (1974). Hypertension as an ingredient of a cardiovascular risk profile. British fournal of Hospital Medicine, 11, 508-523.

Kannel, W. B., Gordon, T., Castelli, W. P., and Margolis, J. R. (1970). Electrocardiographic left ventricular hypertrophy and risk of coronary heart disease. Annals of Internal Medicine, 72, 813-822.

Kennedy, R. D., and Caird, F. I. (1972). The application of the Minnesota code to population studies of the electrocardiogram in the elderly. Gerontologia Clinica, 14, 5-16.

Kitchin, A. H., Lowther, C. P., and Milne, J. S. (1973). Prevalence of clinical and electrocardiographic evidence of ischaemic heart disease in the older population. British Heart fournal, 35, 946-953. 
Librach, G., Schadel, M., Seltzer, M., Hart, A., and Yellin, N. (1976). Immediate and long-term prognosis of acute myocardial infarction in the aged. Fournal of Chronic Diseases, 29, 483-495.

McLennan, W. J., Andrews, G. R., Macleod, C., and Caird, F. I. (1973). Anaemia in the elderly. Quarterly fournal of Medicine, n.s. 42, 1-13.

Medical Research Council (1966). Questionnaire on Respiratory Symptoms. M.R.C., London.

Merrell, M., and Shulman, L. E. (1955). Determination of prognosis in chronic disease, illustrated by systemic lupus erythematosus. Fournal of Chronic Diseases, 1, 12-32.

Pathy, M. S. (1967). Clinical presentation of myocardial infarction in the elderly. British Heart fournal, 29, 190-199.

Pomerance, A. (1976). Pathology of the myocardium and valves. In Cardiology in Old Age, p. 11. Ed. by F. I. Caird, J. L. C. Dall, and R. D. Kennedy. Plenum Press, London and New York.
Reid, D. D., Hamilton, P. J. S., McCartney, P., and Rose, G. (1976). Smoking and other risk factors for coronary heart disease in British civil servants. Lancet, 2, 979-984.

Rodstein, M. (1956). The characteristics of non-fatal myocardial infarction in the aged. Archives of Internal Medicine, 98, 84-90.

Rose, G. A. (1968). Variability of angina-some implications for epidemiology British fournal of Preventive and Social Medicine, 22, 12-15.

Rose, G. A., and Blackburn, H. (1968). Cardiovascular Survey Methods. World Health Organization Monograph Series, No. 56.

Requests for reprints to Dr. F. I. Caird, University Department of Geriatric Medicine, Southern General Hospital, Glasgow G51 4TF. 